\title{
BPEME KPИЗА
}

Сажетак: Роман Време чуда Борислава Пекића почива на чврстом међусобном односу идеологије и нарације. С обзиром да се не може приповедати о идеологији с неутралног и објективног становитта, биће детаљно анализирана релација у којој се налазе идеологија романа и идеологија у роману. Образложиће се на који начин наративне стратегије истовремено представљају средство спровођења идеолошких захтева, али и средство юихове дезинтеграције. У раду ће се претежно користити терминологија Луја Алтисера (Louis Althusser) у домену идеологије, а у домену наратологије, терминологија Жерар Женета (Gérard Genette). У закључним разматрањима биће истакнута теза да у извесној мери криза нарачије која је захватила савремену књижевност почива на негирању виталистичке везе (приказане у роману) између идеологије и приповедања.

Кључне речи: идеологија, наративне технике, интерпелација

Нарација почива на претпоставци да је живот подложан разумевању и у њеној природи је да казује какве су ствари и зашто. Међутим, савремена друштвена ситуација и идеолошка систематизација света сабија људску свест на тако мали простор одакле живот нужно изгледа несводив. Притисак на наративне конструкције с геополитичког врха утолико је јачи уколико је простор за слободну обраду неизрецивог мања. Српска књижевна сцена посегнула је за приповедањем у првом лицу у нади да се субјективној интерпретацији света не могу наметнути границе, али суочила се с ситуацијом нагомилавања бесмисла. Наратив је почео да се урушава сам од себе.

Парадоксално, идеологија представља чврст ослонац нарацији као референтна вредност у односу на коју нарација организује свој садржај, но с друге стране, она је и њена највећа коб. Идеологија изнутра, као наративни стожер, омогућује стабилну структуру, али као диктат споља доводи наратив у шизофрену ситуацију услед које се губи компас. Време криза је време када је немогуће говорити о стварима и бити 
сигуран да оно о чему говоримо постоји. Време криза траје протеклих пар деценија у различитом облику и готово је узалудно анализирати кризу унутар ње саме. Но, уколико се издигнемо изнад наметнутог наративног хоризонта, можемо препознати благу вест о кризама које следе унутар романа објављеног 1965. године - „Време чуда” Борислава Пекића.

Обновљени модернизам добија нарочити замах у српској прози раних шездесетих година двадесетог века када је објављен роман „Време чуда”, а иновативност самог романа отвара простор унутар српске књижевне традиције за интегралну поетику и књижевни опус Б. Пекића. Роман „Време чуда" припада својеврсном уметничком правцу „писања поетике", за који је сипмтоматично да акумулирано знање о свету и туђи текст у својству алузивног оквира „замењује““،ссам свет. ${ }^{1}$ Сам роман не пати од бољке која захвата савремену књижевност и има изразито стабилну наративну структуру и чврсту композицију. Управо та стаменост омогућава стваралачке поступке попут деканонизације, демитизације и демистификације затворених мисаоних система којим се обликује централна тема - космогонија зла у којој обитава човекова слаба нада. ${ }^{2}$

„Време чуда” стоји у специфичном односу с Новим Заветом. Хипертекстуалност (Gérard Genette) представља књижевни феномен који се манифестује путем појаве да се два текста (или више) и остали артефакти налазе у својеврсној тесној међусобној вези, а да се при томе један текст не може назвати пуким одјеком другог. Сам однос између хипертекста и хипотекста не заснива се само на цитатима и алузијама, већ је однос утемељен и поступцима као што су трансформација, модификација, елаборација и проширивање.

Интерактивна спрега између два текста ствара поље на коме се огледа међусобна повезаност између идеологије и нарације. На први поглед може се рећи да пекићевска параболична мисао критикује хришћанско учење, но заправо, чинећи смешном хришћанску догму, Пекић контекстуализује тоталитаризам и социјалистичко-комунистичку идеологију, док у крајњој инстанци, демистификује вечне принципе идеологије. Оно што нас занима јесте форма идеологије а приори и корелативна веза с наративним стратегијама.

1 Пијановић, П. Ново читање Б. Пекића, у: Поетика Борислава Пекића - преплитање жанрова, приредио Пијановић, П. и Јерков, А. (2009), Београд: Службени гласник, стр. 25.

2 Пијановић, П. (1991) Поетика романа Борислава Пекића, Београд: Просвета, стр. 289. 
Идеологија нема историју. ${ }^{3}$ Идеологија представља аисторијску категорију и омниисторијску реалност, у смислу да су структура и функционисање непроменљиви и присутни у истој форми кроз оно што називамо историјом. ${ }^{4}$ Постоје различите дефиниције шта је то идеологија, али посматрање идеологије као „представе” имагинарног односа индивидуа према њиховим реалним условима егзистенције ${ }^{5}$, чини нам се најближе стварном стању ствари. Ови имагинарни односи, тзв. погледи на свет, иако представљају илузију и не кореспондирају са стварношћу, на један специфичан начин ипак алудирају на ту исту реалност. ${ }^{6}$ Луј Алтисер (Louis Althusser) у свом раду „Идеологија и државни идеолошки апарати" наглашава да идеологија у својој нужно имагинарној деформацији не представља постојеће производне односе, већ однос индивидуе према постојећим производним релацијама. У даљем испитивању долази до открића да иако по природи имагинарна, идеологија увек егзистира у пракси из чега произилази да је њена егзистенција материјална.

Луј Алтисер уводи појам интерпелащије који се односи на идеолошки позив који се кроз идеолошку праксу и идеолошке чинове упућује појединцу, а чијим прихватањем појединац улази у сферу доминантних представа и тиме стиче културни (идеолошки) идентитет. Моменат препознавања да је позив баш њему упућен, а не неком другом, чини од индивидуе која се препознала јединствен (идеолошки) субјекат. Л. Алтисер често наводи као пример полицијско заустављање „Хеј, ти!” приликом ког ће дотична особа препознати да је позив баш њој, а не неком другом појединцу, упућен. Дакле, у тренутку препознавања долази до трансформације и регрутащије индивидуе у јединствен субјекат, а уколико до препознавања не дође, то није добро.

У роману „Време чуда” системски је приказано шта се дешава у случајевима када индивидуа не препознаје идеолошку интерпелацију. У неком крајње баналном свођењу фабулативног низа унутар романа, добијамо ситуацију у којој на идеолошки позив у форми „Хеј, ти, што вапиш за чудом!”, индивидуа одговара „А ко то?”.

У роману се демистификује дискурзивно идеолошко деловање и разоткрива се идеолошки механизам заснован на семио-техници кажњавања и умећу предочавања. Другим

3 Алтисер, Л. (2009) Идеологија и државни идеолошки апарати, Београд: Карпос, стр. 48.

4 Исто, стр. 50.

5 Исто, стр. 53.

6 Исто. 
речима, Исусова чуда уместо да представљају благослов с неба и величину божанског милосрђа, будући нежељена, откривају се као претежно телесни облици кажњавања над индивидуалцима који не прихватају уврежени систем вредности. Предочен је персонални доживљај чуда као трауме унутар наратива. Проговориће онај који није то тражио, прогледаће онај који није то желео, проходаће онај који је то избегавао, а они (народ) који видеше шта се на юихове очи зби, дивљаху се врло, и човеку који то учини вероваху да долази у име Господа, чији је јединородни Син, да их избави од греха и невоље сваколике, и да их чисте преда у наручје неба ${ }^{7}$.

Слободна људска воља може бити слободна само у оној мери у којој се поклапа са идеолошки детерминисаном слободом - домет слободе се огледа у слободном потчињавању владајућој идеологији. У роману се приказује обележено и кажњено (прилагођено) тело и ефекат који произилази из вештог утицања на обраду информација, односно, перцепцију већине.

Човек је идеолошка животиња по природи ${ }^{8}$ представља став који објашњава потребу већине да усваја имагинарне представе света око себе. Човек је заправо биће без ослонца, и као такво, по инерцији тежи систематизованој идејној структури унутар које ће моћи да утемељи и осмисли своју властиту егзистенцију. Немање свести о идеолошкој природи (било ког) система идеја, нагони човека да материјално егзистирање идеологије кроз праксу и апарате посматра као ствари по себи, као реалне чињенице. У том случају, добро за мене мора бити добро и за другог.

Идеолошко умеће предочавања почива на манипулацији односима између означитеља и означеног. Означитељ задржава значење из првобитне релације, али се преноси и означава нешто сасвим друго. Таквим поступањем долази до мимикрије најпре веома важног удела намере у домену моралног деловања, а затим се нарушава и право појединачних избора. Чуда се не спроводе да би отклонила патњу човека и да би учинила добро, она се спроводе јер то тако мора, јер то захтева идеологија старозаветног текста.

Злоупотребом разних појмова креира се низ представа које врлину одржавају као такву, а затим преображавају и маскирају оно што њоме бива означено. У поглављу „Смрт на Морији” представа о бризи за човеково здравље ће бити

7 Пекић, Б. (2012) Време чуда, Београд: Лагуна, стр. 355.

8 Алтисер, Л. нав. дело, стр. 65. 
раскринкана као императив принудног рада који није у служби човечијег благостања, већ у служби оних на позицији израбљивача. Захваљујући чуду, Варлаам из Раматаима ће проходати и његов срећан просјачки живот биће окончан у ефраимском рудокопу далеко од Јерусалима, где ће за бедну наднииу, ни принети просјачкој заради, аргатовати од црног јутра до још ирње вечери ${ }^{9}$.

Чуда бивају разоткривена као сила која не узима у обзир човека и његове потребе, већ циљ који треба да се постигне. Међу крајњим резултатима и јесте потврђивање парцијалних интереса као општих, што представља основну карактеристику непроменљивог идеолошког устројства. Физичка способност и рад као благослов само су једна од многих премиса комунистичко-социјалистичке идеологије која бивају демаскирана у роману „Време чуда”. Међутим, контекстуализујући и критикујући комунистичко-социјалистичку догму, Пекић ипак на централној идеји хришћанства идеји о спасењу - показује фундаментални принцип вечног идеолошког механизма.

Луј Алтисер анализира хришћанску идеологију и примећује да Бог као Субјект (Ја сам онај који јесам, тј. Субјекат par excellence) интерпелира субјекте-саговорнике, и на тај начин они постају његова огледала, његови одрази. Структура идеологије која интерпелира индивидуе као субјекте у име Јединственог и Апсолутног субјекта, јесте спекуларна, тј. огледална структура. Апсолутни Субјекат заузима јединствено место Центра и интерпелира бесконачно мноштво индивидуа као субјекте. ${ }^{10}$ Поједини јунаци романа „Време чуда" су се препознали и прихватили идеолошку интерпелацију. Чин прихватања најбоље се огледа у Јудином понашању. Јуда нек се збуде режира чуда према старозаветном тексту и таквим поступањем открива причу као нешто што се може преносити из медија у медиј ${ }^{11}$.

Обрнута мимеза, за разлику од мимезе, заснива се на подражавању речи. Принцип обрнуте мимезе препознаје се у доследном превођењу исприповеданих (антиципираних) догађаја у стварносни регистар, зарад остваривања централне идеје о спасењу човечанства. Оно на шта треба обратити пажњу јесу сигнали који указују на заметак идеологије и идеолошких механизама унутар максиме у почетку беше Реч. Најпре реч, текст у најширем смислу, а потом материјална

9 Пекић, Б. нав. дело, стр. 355.

10 Алтисер, Л. нав. дело, стр. 77.

11 Римон-Кенан, Ш. (2007) Наративна проза, Београд: Народна књига Алфа, стр. 17. 
реалност. Али реч је оно што јесте, и не може бити ништа друго, а човекова тежња да реч постане искуство отвара простор за деловање идеологије као имагинарне представе односа индивидуа према реалним условима егзистенције. Улаже се огромна енергија и напор да се транспонује реч у дело, да се идеја отелотвори, односно, да се одржи илузија остварених речи.

Међутим, нема ничег на овом свету што се није удаљило од своје идеје (Blaise Pascal), па и од речи. Негативна конотација произилази не из саме потребе човека да оствари текст, већ из последица које су неизбежне приликом опсесивног поступања. Страшна је заробљеност унутар затвореног мисаоног обрасца, али је још страшнија немогућност да се разуме да је језички низ који ствара текст увек линеаран и да почива увек на каузалном принципу где једно следи иза другог, насупрот реалној егзистенцији која је истовремена и свеобухватна. Због тога ће увек текст остати текст, а живот нешто сасвим друго.

Спасење света представља динамички мотив у роману, узрок је и циљ целокупном развојном току романа. Представља парцијални интерес као општи у оној мери у којој Јуда препознаје да тако треба да буде, да тако бити мора, да је тако најбоље за све. Индивидуално се поставља као цена и колатерална штета на путу најбољем од свих путева.

Дакле, супротстављају се два начела, с једне стране индивидуалност као мера света, а с друге, тоталитарност и изједначавање у масовности као апсолутне вредности. У том стремљењу ка тоталитету, низање чуда према старозаветној речи се приказује и као поступак аналоган истражном поступку инквизиције у средњем веку. Истина о васкрсењу и спасењу света је већ позната као таква, само је треба потврдити. Принцип крив док се не докаже невиност, а не невин док се не докаже супротно, чуда организује с једне стране, као процес доказивања, а са друге стране, као мучење/ кажњавање. Доказни материјал јесте физичко тело, но, оно у самом процесу поприма још неке особине и функције.

Казна је у оквирима различитих друштвених модела претрпела бројне промене приликом одређивања казнене сврховитости, али у раним друштвеним организацијама имала је претежно корективну функцију. Казном се сузбијао злочин, односно, све социјалне абнормалности и аномалије. А само нормирање шта представља друштвени деформитет, а шта не, спроводило се и спроводи се путем владајуће идеологије. Будући да су сва приказана чуда у роману извршена над појединцима чија уверења и потребе одступају од 
уврежених, њихов злочин се лоцира не у самим чињеницама да немају могућност да говоре, гледају, ходају, итд., већ што у томе уживају. На тај начин, они не признају идеале који претендују да буду идеали свих и тиме се нарушава деловање идеологије изнутра. Појединци су казном насилно и неопозиво осакаћени по мери властитог злочина, а њихова слободна воља укинута зарад сузбијања индивидуалности. Циљ неопозивог кажњавања јесте интеграција друштвеног тела ради лакшег идеолошког манипулисања.

Но поврх свега - осим што се кажњавањем физичког тела ствара јединствено и једноумно друштвено тело, истовремено се појединачно физичко тело претвара у наративно тело. Телесност постаје означитељ, односно место на којем је написана порука. ${ }^{12}$

Субверзивно деловање идеологије заснива се на коришћењу тела као најмање јединице значења. Повезана у одређени сукцесивни ред, тела творе означитељски ланац идеологије. Такав означитељски ланац представља границе и окове илузије унутар које се креће појединац - златни кавез идеологиje. Да би били интегрисани у јединствено друштвено тело, индивидуалци у роману казном бивају одељени од свог тела као од другог и доживљај сопственог тела се претвара у доживљај страног, неразумљивог, туђег. У поглављу „Чудо у Магдали", које можда најверније приказује терор над путеношћу, описане су муке Марије Магдалене и њој сличних: Тело нам као сужањ беше стегнуто гвозденим веригама чуда..$^{13}$

Казна и порука бивају спојене у наративном телу, а оно за шта се испоставља да превазилази размере засебних епоха и историјских интервала јесте просторни статус тела. Лазарево тело постаје прототип сваког тела над којим се врши насиље више силе:

Он(о) је поста(л)о величанствено поприште битке за спасене света. Његово јадно, старачко, измрвљено тело, које је у равној мери искусило болове умирања и болове поновног рађања, тако да их је једва разликовало, беше постало савремена долина Или, о коју су се газећи је отимали: некад војска Израиљаича и Филистејацุа, данас садукеја и хришћана, сутра ко зна чија. ${ }^{14}$

12 Брукс, П. (2000) Тело и приповедање, Часопис за књижевност и културу, и друштвена питањ $а$ - Реч бр. 57/3, стр. 263.

13 Пекић, Б. нав. дело, стр. 189

14 Исто, стр. 257. 
Претварањем физичког тела у наративно активира се специфични однос између тела и речи: тела су инструменти речи, груба оруђа судбине ${ }^{15}$. Осакаћена (наративна) тела индивидуалаца постају простор за исписивање идеолошких порука: видите, чуда су могућа, васкрсење је истина, живећемо дуго у једнакости и раду. Умеће предочавања је суптилна дисциплина и огледа се у специфичном знаковном манипулисању. Међутим, и сам роман „Време чуда“ представља својеврсно знаковно манипулисање. Шта се догађа се идејном подлогом коју заступа текст? Каква је идеологија текста насупрот критикованој идеологији у тексту?

Идеологија текста, услед демистификације идеологије једнакости и осакаћеног (наративног) тела, истовремено намеће свој вредносни регистар и сопствену интерпретацију. Приповедач се налази на позицији оног што организује видно поље и не може се игнорисати чињеница да говори искључиво о појединцима што чуда доживеше као трауму. То не значи да доживљај тих појединаца није такав, али исто тако не значи ни да је доживљај свих што осетише снагу и моћ чуда такав. Приповедач прави избор, односно, под маском да представља тоталитет света он бира сегменте који ће бити виђени кроз његов говор и интерпретирани на одговарајући начин.

Нарација по инерцији тежи синтези, целини, смислу, а то значи само да се по инерцији наративни текст усмерава ка затвореном систему мишљења. Долази до парадоксалне ситуације у којој наратор покушава да осуди затворене мисаоне обрасце правећи други затворени мисаони образац.

Међутим, Пекић честим променама наративних техника не допушта да се текст сасвим затвори у једну непроменљиву целину. Роман „Време чуда” има више различитих наративних инстанци. Присутан је мултиперспективизам у појединим поглављима, а у одређеним деловима употребљени су и Јудини дневнички записи и посланица, написани у првом лицу.

Ипак, хетеродијегетички приповедач који нити учествује у причи нити је сведок представља глас који организује наратив у већој мери. Поузданост хетеродијегетичког приповедача се може мерити кроз коментаре као ауторитативне описе фикционалне истине. ${ }^{16}$ Ауторски коментар наликује традиционалном облику ауторских уплитања и објашњавања са пиједестала општеприхваћених очекивања, са становишта

15 Исто, стр. 269.

16 Римон-Кенан, Ш. нав. дело, стр. 127. 
„гласа јавности”. ${ }^{17}$ Но, коментар у роману често упућује на не баш тако неутралног и свезнајућег приповедача.

Арбитрарност приповедања откривају сигнали попут рекао бих, ми се овде трудимо да, мада ово није најприкладније место, користимо га да упознамо читаоиа, итд. Наглашен је труд који наратор улаже да прикаже тоталитет фиктивног света чиме се релативизује успех истог. Међутим, приповедач истовремено поседује висок степен самосвести и свести о приповедању, и тиме успешно маскира своју позицију и остварује ефекат делимичног поверења код наратора.

Наратор често проверава проходност комуникативног канала и на тај начин открива своју временску дистанцу и властити систем резоновања. Коментари које оставља при кретању на временској оси представљају елементарне јединице у функцији креирања идејног света романа, и као такви, врше велики утицај на рецепцију текста. Приповедач најпре својом одлуком шта ће се и из ког угла посматрати, а затим коментарисањем посматраног, креира захтев који се упућује читаоцу о позицији коју треба да заузме, уколико жели да учествује у читању. Наратор упућује идеолошки позив читаоцу, интерпелацију, а прихватањем овог позива читалац улази у сферу наметнутих представа и тиме стиче културни (идеолошки) идентитет. ${ }^{18}$ Читалац се изједначава с наратором, калупећи свој идентитет према чистом текстуалном конструкту. Референтну вредност има идеологија индивидуализма.

Као мотив, индивидуализам је угрожен унутар наративне приповести, а што је већи степен страдања индивидуалаца, то је интерпелација упућена читаоцу снажнија. Оно што читалац не види јесте парадокс у који упада: од њега се захтева да препозна заједнички систем вредности и да осуди аутоматизован одговор на интерпелацију, а управо је читалац тај који позитивно реагује на идеолошки позив без свести о томе. Читалац бива принуђен да осуди социјалистичкокомунистичку идеологију и афирмише идеологију засновану на начелима индивидуализма.

Али, постоји нешто што ће пореметити такав след и отрезнити читаоца. Приликом финалног окршаја између идеологије о којој се приповеда и идеологије текста, на самом крају фабулативног низа, долази до неочекиваног разрешења. Наиме, Исусово бекство представља једини (некажњени)

17 Јеремић, љ. (2007) О српским писиима, Нови Сад: Српска књижевна задруга, стр. 242.

18 Бужињска, А. и Марковски, М. П. (2009) Кюижевне теорије XX века, Београд: Службени гласник, стр. 586. 
индивидуални чин у роману, и као такав, симболички одражава победу идеологије текста. Исус реагује негативно на интерпелацију и непрепознавањем себе као јединственог субјекта, урушава хришћанску/социјалистичко-комунистичку идеологију изнутра. Успевши да се одупре наметнутој улози унутар дискурса једнакости, задаје се последњи и коначни ударац у срж наметнутог система представа.

Идеологија текста је доказала своју превласт, али читалац не добија сатисфакцију већ болно отрежњење. Исусовим поступком истовремено се демистификује идеологија индивидуализма као подједнако антихуманистички систем, дијаметрално супротан основним карактеристикама идеологије која бива смењена, а опет, њој близак. Идеологија се открива као омнипотентна, вечна и антихуманистичка, без обзира на садржај за који се залаже.

Наизглед парадоксално, антихуманизам представља горки талог искуства дубоко укорењен у темеље заједница. Друштвена и културна уређења непрекидно производе идеолошке представе, јер би у супротном тешко успеле да одрже заједницу на окупу. Представе и илузије почивају на принципима који представе и илузије одржавају, а не на принципима на којима се темељи сам живот. У том смислу, идеологија је антиживотна, па самим тим и антихуманистичка. Антихуманизам се огледа у идеолошком заборављању на човека унутар заједнице због ког и настаје, а очигледан је када се идеологија налази на сопственом врхунцу и настоји да се оствари у потпуности. Антихуманизам је својствен идеологији и јавља се као последица тежње ка целовитом и затвореном систему. Чин Исусовог бекства као врхунац индивидуалног делања, у крајњој инстанци, омогућава да се замисли песимистичка перспектива идеологије индивидуализма. Но, роман тим чином откупљује своју слободу.

Идеологија текста остаје непромењена, али уз повремену смену наративних гласова, релативизацију ауторског коментара и на крају, откривањем слободног индивидуалног чина као подједнако разорног по човечанство - текст унутар своје идеологије оставља пукотине и на тај начин осујећује потребу наратива да се заокружи, затвори; осујећује потребу за тоталитетом. Наративне технике у свом дисконтинуитету изнутра урушавају апсолут романа. Композициона решења (епизодна организација фабуларних јединица, слаба повезаност између појединачних поглавља, концепција двокњижја, итд.) подједнако учествују у константној разградњи целине. 


\section{ИРЕНА ЂУКИЋ}

Нарација ствара пукотине слободе у наративном тексту који неизбежно обилује значењима узглобљеним у различите идејне системе. Идеологија нужно настаје у процесу приповедања, а даље идеолошко одржавање и деловање заснива се на наративним техникама као примарном оруђу.

Криза у коју је запала нарација данас делом почива на игнорисању интерактивне везе између идеологије и нарације. Бежи се од чињенице да је нарација идеолошко средство и да идеологија произилази из приповедања. Инсистира се на безидеолошком садржају, што је пука илузија и води ка нагомилавању бесмисла. Без идеје, а самим тим и идеологије као одређеног система идеја, наратив се урушава сам од себе. Постоји снажна интенција да се означитељски ланац приближи што више самом појму и да се тако избегну идејни системи, али насупрот очекивањима долази до расплињавања на неразумљива муцања. Излазак из кризе налази се у проналажењу праве дистанце између несводиве реалности која нас окружује и идеја које нас воде. Само на тај начин, наратив и нарација могу опстати.

\section{ЛИТЕРАТУРА:}

Пекић, Б. (2012) Време чуда, Београд: Лагуна.

Пијановић, П. (1991) Поетика романа Борислава Пекића, Београд: Просвета.

Пијановић, П. и Јерков, А. (2009) зборник радова, Поетика Борислава Пекића - преплитање жанрова, Београд: Институт за књижевност и уметност, Службени гласник.

Јеремић, Љ. (2007) О српским писиима, Нови Сад: Српска књижевна задруга.

Римон-Кенан, Ш. (2007) Наративна проза, Београд: Народна књига - Алфа.

Брукс, П. (2000) Тело и приповедање, Часопис за књижевност и културу, и друштвена питања - Реч бр. 57/3.

Бужињска, А. и Марковски, М. П. (2009) Кюижевне теорије XX века, Београд: Службени гласник.

Алтисер, Л. (2009) Идеологија и државни идеолошки апарати, Београд: Карпос. 


\title{
ИРЕНА ЂУКИЋ
}

\author{
Irena Đukić \\ University of Belgrade, Faculty of Philology, Belgrade
}

\section{TIME OF CRISES}

\begin{abstract}
This paper analyzes a specific relationship between ideology as an antihistorical category and the narratives underlying the novel The Time of Miracles by Borislav Pekić. It highlights the key features of immutable and always the same ideological mechanisms, regardless of the contents of ideas in whose name they act. Among many ideological tools, there is narration as a primary means to produce an ideological system as an instrument of action based on the perception of community. However, narrative techniques also represent the only means that enables freedom. By forgetting about the symbiosis of ideology and narrative, the Serbian literary scene is at a narrative crisis due to its sterile wandering through the text. The solution out of the crisis is not in ignoring the ideological nature of storytelling, but in finding the right distance between the complex reality that surrounds us and the ideas that guide us.
\end{abstract}

Key words: ideology, narrative techniques, interpellation

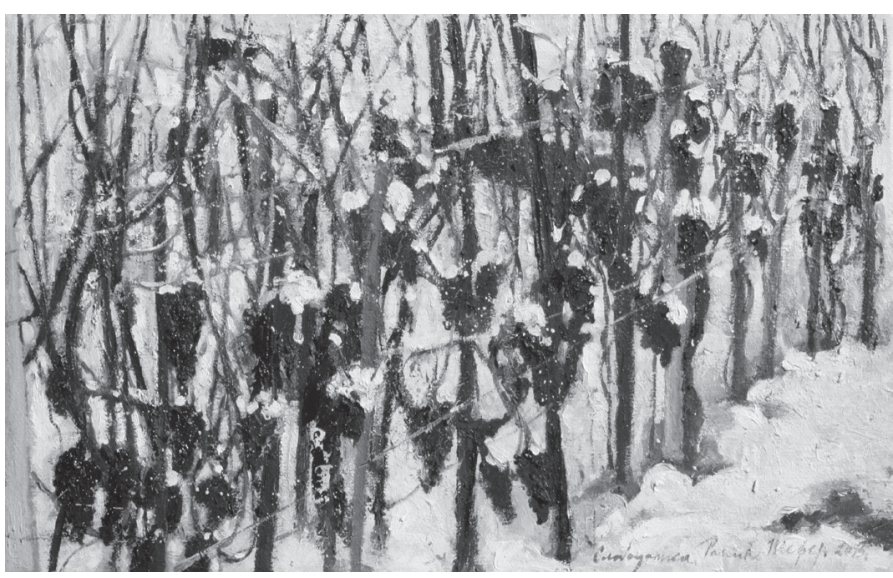

Слободанка Ракић Шефер,

Ледене бобице за ледено вино, уље на платну, 2015. 